\title{
Environmental and stock effects on spatial distribution and abundance of mature cod Gadus morhua
}

\author{
Gavin A. Begg*, Gudrun Marteinsdottir \\ Marine Research Institute, Skulagata 4, PO Box 1390, 121 Reykjavik, Iceland
}

\begin{abstract}
Identification of environmental and stock effects that influence the spatial distribution and abundance of a spawning stock is necessary for understanding stock and recruitment processes, but data on such effects are rare. We examined environmental (depth, temperature), locational (latitude, longitude), and stock (length, age) effects on the distribution and abundance of mature and spawning cod Gadus morhua in Icelandic waters. Generalized additive models (GAMs) were used to test the effects of these covariates on data collected from historic groundfish surveys (1985 to 1999) around the onset of spawning. Mature cod were present in waters all around Iceland, with persistent concentrations in any given year (indicative of regional spawning components) off the southwest, southeast, and north coasts. Depth, temperature and, more importantly, location were significant covariates affecting both the relative abundance of mature cod and the spatial distribution of spawning cod. Incorporating the effects of these covariates and their underlying relationships into stock and recruitment processes will provide insight into the mechanisms involved in population structuring of cod in Icelandic waters.
\end{abstract}

KEY WORDS: Stock · Recruitment · Environment · Generalized additive models · Population dynamics

Resale or republication not permitted without written consent of the publisher

\section{INTRODUCTION}

Spatial distribution and abundance patterns provide fundamental information that often enables delineation of geographic regions which may be representative of individual spawning stocks (Pawson \& Jennings 1996, Begg et al. 1999). Partitioning a spawning stock into smaller population components that represent distinct geographic regions and their associated ambient environmental conditions may facilitate our understanding of stock and recruitment variability (Marteinsdottir et al. 2000a). A diverse spawning stock, comprised of multiple spawning components, distributed over a large-scale geographic range, is likely to spawn in regions providing optimal environmental conditions

\footnotetext{
*Present address: CRC Reef Research Centre, James Cook University, Townsville, Queensland 4811, Australia.

E-mail: gavin.begg@jcu.edu.au
}

for progeny survival and recruitment success (Begg \& Marteinsdottir 2000). Spawning diversity disperses the mortality risk of early life history stages by increasing the spatial and temporal range over which progeny originate (Marteinsdottir et al. 2000b). This enhances progeny survival by increasing the probability that a portion of the population will experience favourable environmental and stock conditions (Cushing 1990, Mertz \& Myers 1994). Indeed, given that spatial distributions of a spawning stock may represent evolutionary adaptations to localized circulation patterns that optimize progeny survival (Parrish et al. 1981, Sinclair 1988), recruitment success may be determined as much by the relative distribution of a spawning stock as by its absolute abundance (DeYoung \& Rose 1993).

The Icelandic cod Gadus morhua stock has been in a depleted state since the mid-1980s, characterized by low spawning stock biomass (SSB) and recruitment, and a weak and uncertain stock recruitment relation- 
ship (Schopka 1994, Marteinsdottir \& Thorarinsson 1998). Historically, most of the total egg production and recruitment of the stock were considered to derive from the main spawning component off the southwest coast (Sæmundsson 1924, Jónsson 1982). However, recent studies have suggested that smaller spawning components located around the country may be contributing more significantly to the overall productivity of the stock than was previously considered (Begg \& Marteinsdottir 2000, Marteinsdottir et al. 2000a,b). The relative contributions of these spawning components may vary each year, depending on localized environmental and stock conditions (Marteinsdottir et al. 2000a). Historic distribution patterns, therefore, may provide an indication of changing stock status and enable fluctuations in stock abundance to be predicted. Consequently, recognizing the underlying mechanisms that govern spatial distribution and abundance patterns may assist in defining assessment predictions and maintaining long-term sustainability of a spawning stock.

We aimed at modelling relationships between spatial distribution, abundance, and ambient environmental conditions experienced by mature and spawning cod in Icelandic waters to enable predictions of where the majority of the spawning stock are located at the beginning of the spawning season in any given year. Statistical reconstruction of annual changes in the relative abundance of mature cod and spatial distribution of spawning cod in relation to depth, temperature, and geographic location were modelled using generalized additive models (GAMs) on data collected from historic groundfish surveys (1985 to 1999) around the onset of spawning. These models were used to provide a basis for revealing the causes of historic changes in the distribution and abundance of the spawning stock, with an aim to improving our knowledge of recruitment variability in the Icelandic cod stock.

\section{MATERIALS AND METHODS}

Data on spatial distribution, abundance, and biological characteristics of mature cod were obtained from the annual (1985 to 1999) spring groundfish surveys conducted by the Marine Research Institute (MRI), Iceland. The surveys coincided with the beginning of the spawning season for cod, and were aimed at minimizing possible biases due to spawning migrations (Pálsson et al. 1989). Sampling was carried out for 2 to $3 \mathrm{wk}$ in March, via a stratified systematic survey, whereby the station locations were fixed around the country (Fig. 1). At each station, most cod were measured (cm), and sex and maturity stage $(1=$ immature, 2 = ripening, 3 = spawning, 4 = spent) was determined macroscopically following the stages defined by Powles (1958). Depth, temperature, and geographic location at each station were also recorded, and were used to model the effects of ambient environmental conditions on the relative abundance of mature cod and the spatial distribution of spawning cod. In the context of our study, spatial distribution refers to a series of fixedpoint geographic locations defined by latitude and longitude.

The spatial distribution and relative abundance of mature cod were estimated to determine geographic regions consonant with individual spawning components. Measured length distributions were derived for each station, and were scaled accordingly when large tows required counting part of the catch (Pálsson et al. 1989). Logistic regression analysis (Sokal \& Rohlf 1995) was then used to estimate annual maturity ogives (immature $=$ Stage 1 , mature $=$ Stages 2 to 4 ). Maturity ogives were estimated separately for cod in waters 
off northern and southern Iceland because of hydrographical and ecological differences in their ecosystems (Fig. 1). Horizontal gradients exist between these waters (as defined in Fig. 1), whereby the northern waters are colder and more variable than the southern waters (Malmberg \& Kristmannsson 1992), creating spatially diverse environments that may influence life history characteristics such as growth, survival, and maturity. Hence, spatially disaggregated (i.e. north/ south) maturity ogives were applied to the appropriate length distributions at each station to estimate the proportion of mature cod at each length $\left(M_{1}\right)$. A relative abundance index $\left(A_{i}\right)$ of mature cod (number nautical mile ${ }^{-1}$ ) at each station (i) was then estimated according to the following relationship:

$$
A_{i}=\frac{1}{Z_{i}} \sum_{l=1}^{l e n} N_{l} \cdot M_{l}
$$

where $N_{l}=$ number of cod measured at each length (l), and $Z_{i}=$ tow distance $(\mathrm{nm})$.

GAMs were used to examine relationships between ambient environmental conditions and the relative abundance of mature cod and the spatial distribution of spawning cod. GAMs are non-parametric generalizations of multiple linear regressions that are not restricted to specific functional relationships (i.e. linearity) or underlying statistical distributions (i.e. normality) of the data (Hastie \& Tibshirani 1990, Swartzman et al. 1992). Hence, GAMs can be useful for examining environmental and stock relationships that are unlikely to be monotonic, linear, or parametric (Maravelias \& Reid 1997). In GAMs, the dependent or response variable is modelled as the additive sum of unspecified covariate or predictor variables, whereby scatterplot smooths replace the least-squares estimates used in multiple linear regression (Hastie \& Tibshirani 1990). The general form of a GAM assumes that the mean response $(\mu)$ is related to the predictor variables $\left(X_{1}, \ldots, X_{p}\right)$ by the following relationship:

$$
g(\mu)=\alpha+\sum_{j=1}^{p} f_{j}\left(X_{j}\right)
$$

where $g(\mu)=$ link function defining the relationship between the response and the additive predictor, $\alpha=$ intercept term, and $f_{j}=$ unspecified smooth function. The observed response is assumed to obey some underlying statistical distribution from the exponential family (e.g. Gaussian, Poisson, binomial, or Gamma distributions) with the specified mean, $\mu$ (Hastie \& Tibshirani 1990).

GAMs were used to examine the annual effects of depth, temperature, and geographic location (latitude and longitude) on the relative abundance of mature cod. We used the Poisson distribution for these models because it was considered appropriate for random count data, and because dispersion of the data was approximately equal to 1 in most years (Sokal \& Rohlf 1995). For each year (1985 to 1999), all the main covariates and their first-order interaction terms were included in an initial model. Backward, stepwise, variable selection and model fit were then used to determine a set of significant covariates based on analysis of deviance, approximate $F$-tests, and residual deviance plots (Hastie \& Tibshirani 1990). An additional measure of model fit was based on a pseudo-coefficient of determination $\left(\mathrm{R}^{2}\right)$, which was the fraction of the total 'variation' accounted for by the model:

$$
\mathrm{R}^{2}=1-\left(\frac{\text { residual deviance }}{\text { null deviance }}\right)
$$

where deviance was analagous to the residual sums of squares (Swartzman et al. 1992). The final GAM used to examine annual environmental effects on the relative abundance of mature cod was:

$$
\log _{\mathrm{e}}\left(A_{i}+1\right)=s\left(D_{i}\right)+s\left(T_{i}\right)+s\left(L a_{i}\right)+s\left(L o_{i}\right)
$$

where the link function $=\log _{\mathrm{e}}$ of mature cod abundance modelled as the additive sum of depth $\left(D_{i}\right)$, temperature $\left(T_{i}\right)$, latitude $\left(L a_{i}\right)$, and longitude $\left(L o_{i}\right)$, and $s=$ cubic B-spline smoother with 4 degrees of freedom (df).

GAMs were then used to examine environmental and 'stock' effects on the distribution (i.e. presence/ absence) of spawning cod. Stock effects were considered to describe biological characteristics (i.e. length and age) of individual cod comprising the spawning stock. We used the binomial distribution for these models with a logit link function (Hastie \& Tibshirani 1990). The GAM used for each year (1985 to 1999) was:

$$
\begin{aligned}
& \operatorname{logit}\left(P_{k}\right)= \\
& s\left(D_{k}\right)+s\left(T_{k}\right)+s\left(L a_{k}\right)+s\left(L o_{k}\right)+s\left(L_{k}\right)+s\left(A_{k}\right)
\end{aligned}
$$

where $P_{k}=$ binary response indicating a spawning (Maturity Stage 3) or non-spawning (Stages 1, 2, and 4) $\operatorname{cod}(k) ; L_{k}=$ length $(\mathrm{cm})$ of each $\operatorname{cod}_{i}$ and $A_{k}=$ age (years) of each cod. GAMs were then used to test for a temporal effect on the relative abundance of mature cod and spatial distribution of spawning cod by combining the respective data for all years in a single analysis for the different response variables (i.e. Swartzman et al. 1992, Maravelias et al. 2000).

Permutation tests were used to determine the significance levels for each of the covariates in the models (Swartzman et al. 1992). Each GAM was run 500 times, with the covariate of interest being permuted against the other covariates in the model. The significance level for the particular covariate was based on the proportion of GAM runs whose pseudo- $R^{2}$ values were greater or equal to that of the pseudo- $\mathrm{R}^{2}$ value of the original GAM (Swartzman et al. 1992). Bootstrap resampling $(500 \times$ with replacement) of the original 
Table 1. Gadus morhua. Results of permutation tests of the significance (p-values) of depth, temperature, latitude and longitude on the relative abundance of mature cod in the final GAMs. The number of permutations used in each test was 500 . Null and residual model deviance, degrees of freedom (df) for each deviance term, and the pseudo-coefficient of determination $\left(\mathrm{R}^{2}\right)$ are also shown for the final Generalized Additive Models (GAMs), 1985 to 1999. $\mathrm{R}^{2}$ values for the initial GAMs correspond to those models with all main covariates and first-order interaction terms included. The year effect was only included in the final temporal model combining the data for all years. ns: not significant at $\mathrm{p}>0.10$

\begin{tabular}{|c|c|c|c|c|c|c|c|c|c|c|c|}
\hline \multirow{2}{*}{ Year } & \multirow{2}{*}{ Depth } & \multirow[b]{2}{*}{ Temp. } & \multirow[b]{2}{*}{ Lat. } & \multirow[b]{2}{*}{ Long. } & \multirow{2}{*}{\multicolumn{2}{|c|}{$\begin{array}{l}\text { Final GAM - } \\
\text { Year } \quad \text { Null dev. }\end{array}$}} & \multirow[b]{2}{*}{$\mathrm{df}$} & \multirow[b]{2}{*}{ Res. dev. } & \multirow[b]{2}{*}{ df } & \multirow[b]{2}{*}{$\mathrm{R}^{2}$} & \multirow{2}{*}{$\begin{array}{c}\text { Initial GAM } \\
\mathrm{R}^{2}\end{array}$} \\
\hline & & & & & & & & & & & \\
\hline 1985 & 0.020 & 0.130 & 0.000 & 0.000 & - & 306.55 & 424 & 238.68 & 408.1 & 0.22 & 0.29 \\
\hline 1986 & 0.000 & 0.002 & 0.004 & 0.000 & - & 328.86 & 468 & 271.49 & 452.1 & 0.17 & 0.25 \\
\hline 1987 & 0.050 & 0.000 & ns & 0.000 & - & 274.38 & 409 & 196.83 & 393.1 & 0.28 & 0.33 \\
\hline 1988 & 0.000 & 0.000 & ns & 0.000 & - & 313.83 & 409 & 248.37 & 393.0 & 0.21 & 0.29 \\
\hline 1989 & ns & 0.000 & 0.000 & 0.000 & - & 477.95 & 488 & 361.83 & 472.2 & 0.24 & 0.37 \\
\hline 1990 & 0.024 & 0.012 & 0.000 & 0.000 & - & 466.88 & 522 & 327.66 & 506.2 & 0.30 & 0.38 \\
\hline 1991 & 0.028 & 0.014 & 0.000 & 0.000 & - & 380.44 & 509 & 313.57 & 493.2 & 0.18 & 0.24 \\
\hline 1992 & ns & 0.000 & 0.016 & 0.000 & - & 416.40 & 582 & 352.59 & 566.2 & 0.15 & 0.23 \\
\hline 1993 & 0.000 & 0.000 & 0.018 & 0.000 & - & 374.16 & 541 & 308.52 & 525.2 & 0.18 & 0.23 \\
\hline 1994 & 0.084 & 0.000 & ns & 0.000 & - & 454.72 & 594 & 387.63 & 578.2 & 0.15 & 0.21 \\
\hline 1995 & 0.060 & 0.000 & 0.000 & 0.000 & - & 473.70 & 573 & 374.82 & 557.2 & 0.21 & 0.31 \\
\hline 1996 & 0.092 & 0.000 & 0.000 & 0.000 & - & 397.26 & 533 & 336.48 & 517.2 & 0.15 & 0.21 \\
\hline 1997 & 0.088 & 0.032 & 0.000 & 0.036 & - & 336.80 & 461 & 283.46 & 445.1 & 0.16 & 0.25 \\
\hline 1998 & 0.006 & 0.004 & 0.000 & 0.010 & - & 405.57 & 497 & 335.77 & 481.0 & 0.17 & 0.27 \\
\hline 1999 & 0.024 & 0.002 & 0.000 & 0.014 & - & 334.41 & 513 & 288.07 & 497.1 & 0.14 & 0.24 \\
\hline All & 0.000 & 0.000 & 0.000 & 0.000 & 0.000 & 5896.73 & 7537 & 5358.34 & 7517.2 & 0.09 & - \\
\hline
\end{tabular}

data was then used to generate model variance estimates $( \pm 95 \%$ confidence intervals) for the smooths of each covariate (Efron \& Tibshirani 1993). For further details see Swartzman et al. (1992). All statistical analyses were performed using Version 5.1 S-PLUS software (MathSoft 1998).

\section{RESULTS}

\section{Distribution and abundance of mature cod}

During the survey period (1985 to 1999), annual variations were observed in the mean length at which $50 \%$ of the cod population were mature $\left(\mathrm{L}_{50}\right.$; Fig. 2 ). In any given year, cod in waters off northern Iceland were estimated to reach maturity at larger lengths than those in waters off southern Iceland (Fig. 2), reflective of slower growth rates that, in turn, may have been influenced by cooler waters (Fig. 3). Consequently, the spatial disparity in maturity schedules between cod in waters off northern and southern Iceland provided support for using spatially-disaggregated maturity ogives in calculations of abundance indices for mature cod.

Mature cod were distributed all around Iceland prior to the onset of the main spawning period (March to May) (Fig. 3). Regional concentrations of mature cod were located each year on or near the main spawning grounds off the southwest coast as well as off the southeast, and northwest coasts, indicative of differential spawning components. Concentrations of mature cod were also located across the entire north coast, although these appeared to be more dispersed and variable in size between years than the other more persistent concentrations off the southwest, southeast, and northwest coasts (Fig. 3). Mean sample (i.e. station) depths were reasonably consistent between years, although bottom temperatures were more variable. In any given year, mature cod in waters off northern Iceland experienced cooler bottom temperatures than cod in waters off southern Iceland (Fig. 3).

Results of the initial GAMs (including all the main covariates and their first-order interaction terms) that were used to examine the relative abundance of mature cod revealed that the interaction terms only contributed a small improvement to the overall model fits. In any given year, inclusion of all the first-order interaction terms in the initial models only increased the pseudo- $\mathrm{R}^{2}$ values of the final GAMs (only main covariates) by 5 to $13 \%$ (Table 1). In addition, none of the interaction terms were significant on a consistent annual basis, and any given interaction term on its own improved only slightly the overall model fits. Although we recognized that a significant interaction term could be quite informative from

Fig. 2. Gadus morhua. Maturity ogives for cod in waters off northern and southern Iceland used to estimate the proportion of mature cod at each length for the sampled length distribution at each survey station, 1985 to 1999. n: sample size; a: intercept term; b: regression coefficient; $\mathrm{L}_{50}$ : length at $50 \%$ maturity 

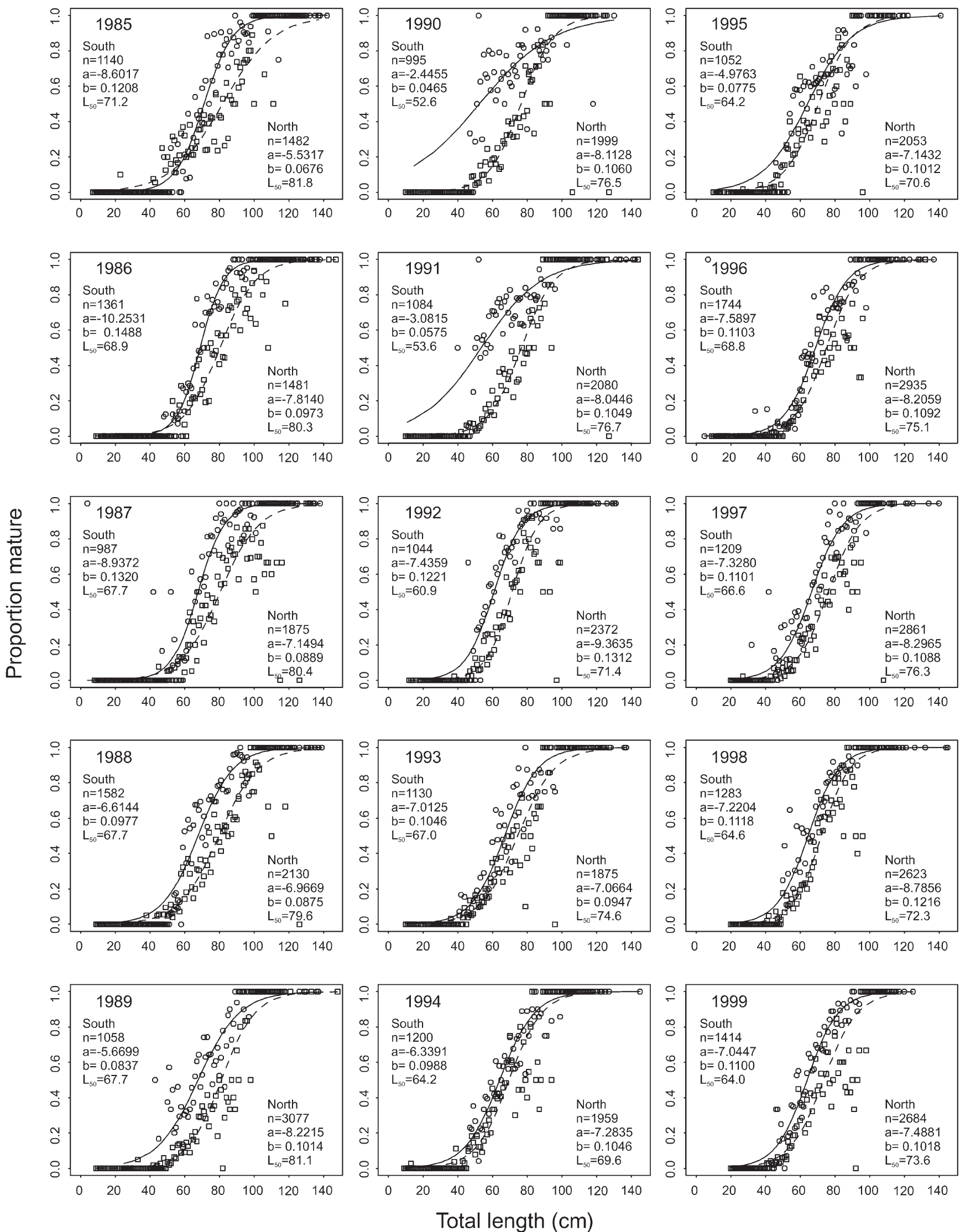

Total length (cm) 

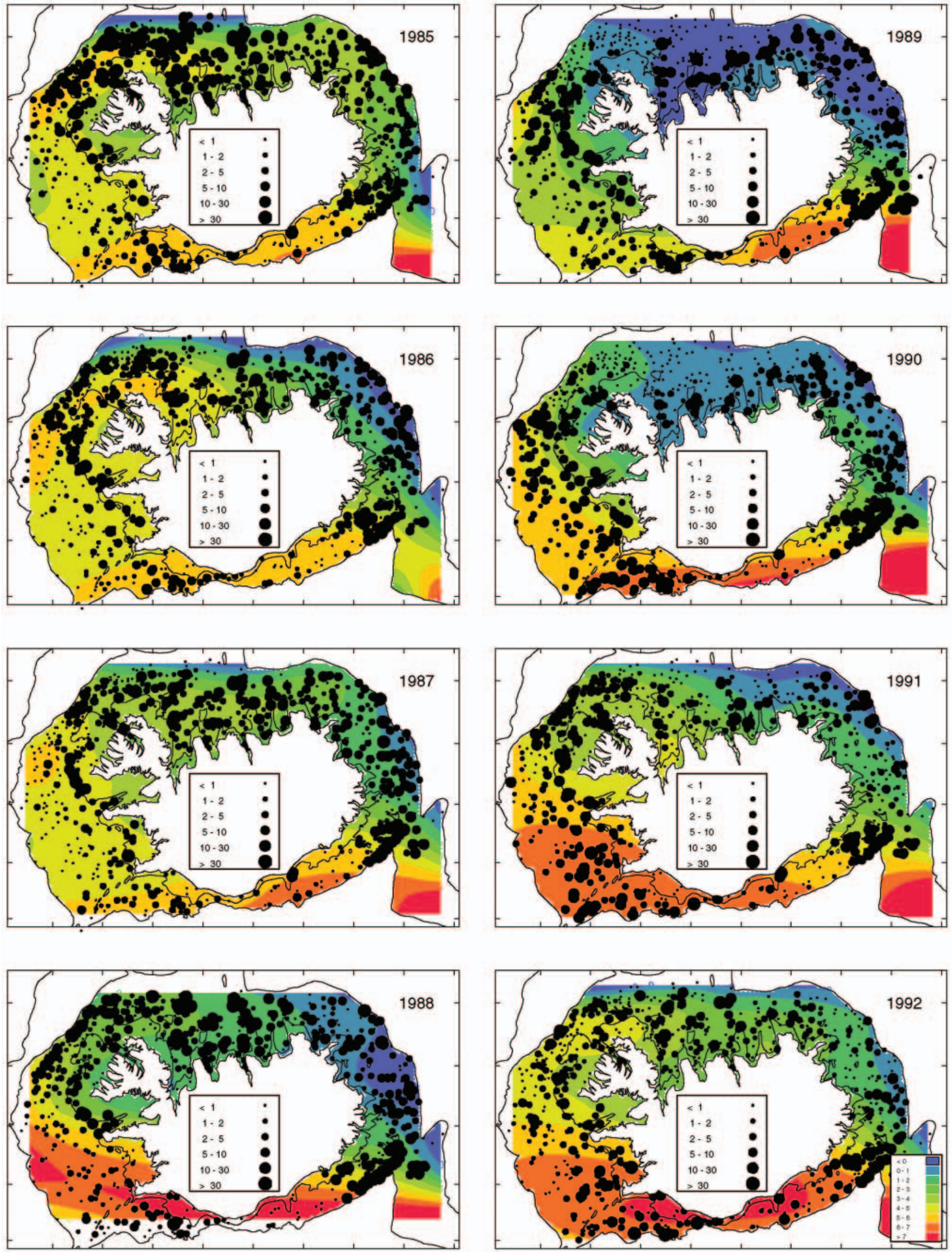

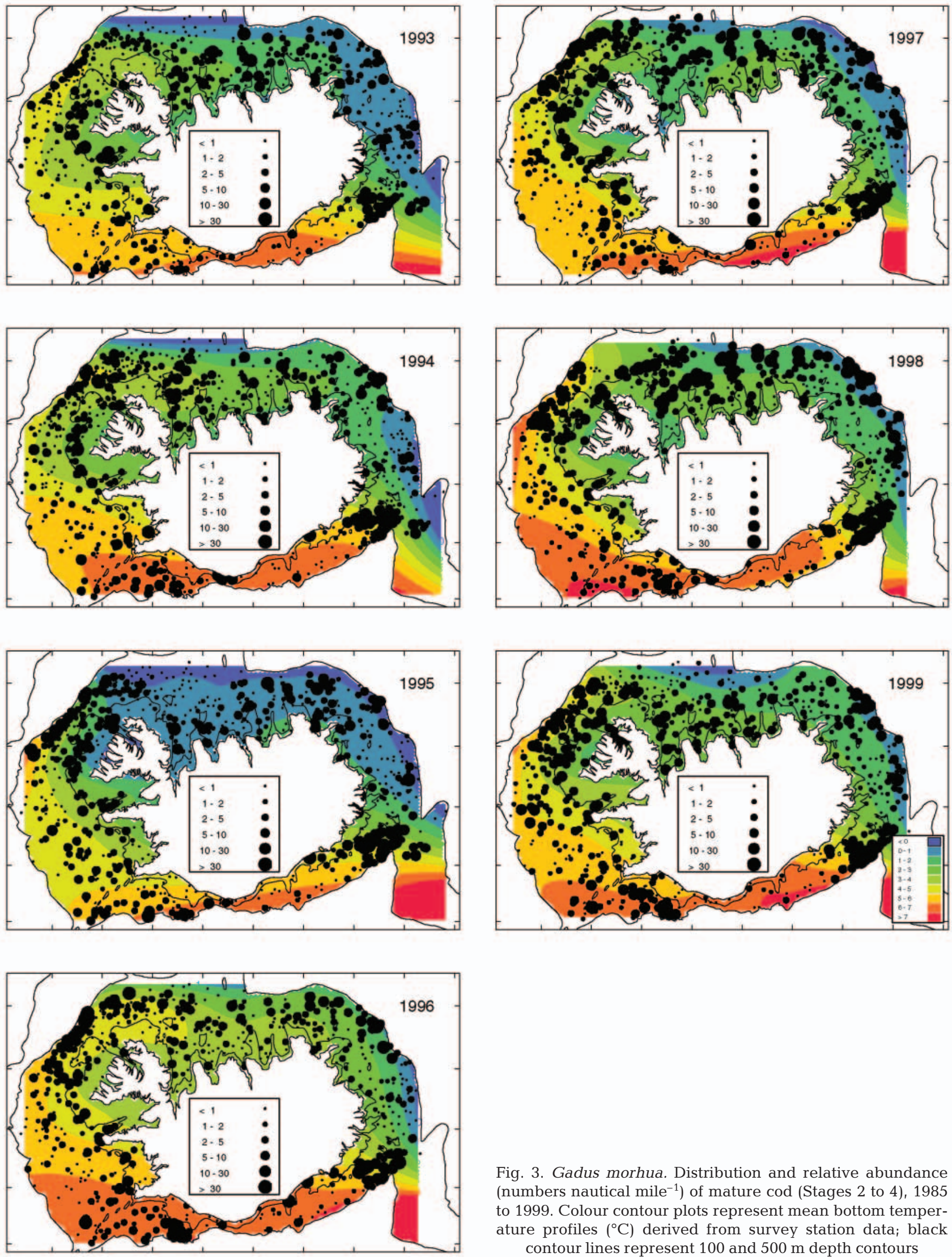

Fig. 3. Gadus morhua. Distribution and relative abundance (numbers nautical mile ${ }^{-1}$ ) of mature cod (Stages 2 to 4), 1985 to 1999. Colour contour plots represent mean bottom temperature profiles $\left({ }^{\circ} \mathrm{C}\right)$ derived from survey station data; black contour lines represent 100 and $500 \mathrm{~m}$ depth contours 
Table 2. Gadus morhua. Results of permutation tests of the significance (p-values) of depth, temperature, latitude, longitude, length and age on the spatial distribution (i.e. presence/absence) of spawning cod in the GAMs. The number of permutations used in each test was 500. Null and residual model deviance, degrees of freedom (df) for each deviance term, and the pseudocoefficient of determination $\left(\mathrm{R}^{2}\right)$ are also shown for the GAMs, 1985 to 1999 . The year effect was only included in the final temporal model combining the data for all years. ns: not significant at $p>0.10$

\begin{tabular}{|rcccccccccrrr}
\hline Year & Depth & Temp. & Lat. & Long. & Length & Age & Year & Null dev. & df & Res dev. & df & $\mathrm{R}^{2}$ \\
\hline 1985 & 0.058 & $\mathrm{~ns}$ & $\mathrm{~ns}$ & $\mathrm{~ns}$ & 0.048 & $\mathrm{~ns}$ & - & 297.86 & $(2116)$ & 182.61 & $(2092.6)$ & 0.39 \\
1986 & $\mathrm{~ns}$ & 0.094 & $\mathrm{~ns}$ & $\mathrm{~ns}$ & 0.024 & 0.092 & - & 108.13 & $(2537)$ & 49.94 & $(2513.6)$ & 0.54 \\
1987 & $\mathrm{~ns}$ & $\mathrm{~ns}$ & 0.000 & 0.000 & 0.000 & $\mathrm{~ns}$ & - & 678.09 & $(2254)$ & 452.95 & $(2230.3)$ & 0.33 \\
1988 & $\mathrm{~ns}$ & 0.060 & 0.022 & 0.000 & $\mathrm{~ns}$ & 0.010 & - & 849.49 & $(2392)$ & 433.93 & $(2368.5)$ & 0.49 \\
1989 & $\mathrm{~ns}$ & $\mathrm{~ns}$ & $\mathrm{~ns}$ & $\mathrm{~ns}$ & $\mathrm{~ns}$ & $\mathrm{~ns}$ & - & 75.04 & $(3342)$ & 35.86 & $(3318.7)$ & 0.52 \\
1990 & $\mathrm{~ns}$ & $\mathrm{~ns}$ & $\mathrm{~ns}$ & 0.074 & $\mathrm{~ns}$ & $\mathrm{~ns}$ & - & 106.88 & $(2347)$ & 52.72 & $(2324.4)$ & 0.51 \\
1991 & 0.004 & 0.012 & 0.020 & $\mathrm{~ns}$ & $\mathrm{~ns}$ & $\mathrm{~ns}$ & - & 512.95 & $(2678)$ & 311.60 & $(2654.4)$ & 0.39 \\
1992 & 0.006 & $\mathrm{~ns}$ & 0.090 & 0.018 & $\mathrm{~ns}$ & $\mathrm{~ns}$ & - & 205.83 & $(2670)$ & 131.68 & $(2646.4)$ & 0.36 \\
1993 & $\mathrm{~ns}$ & $\mathrm{~ns}$ & $\mathrm{~ns}$ & 0.016 & 0.048 & 0.036 & - & 286.47 & $(2842)$ & 184.19 & $(2818.7)$ & 0.36 \\
1994 & $\mathrm{~ns}$ & $\mathrm{~ns}$ & $\mathrm{~ns}$ & $\mathrm{~ns}$ & $\mathrm{~ns}$ & $\mathrm{~ns}$ & - & 72.89 & $(2694)$ & 23.98 & $(2672.7)$ & 0.67 \\
1995 & $\mathrm{~ns}$ & $\mathrm{~ns}$ & $\mathrm{~ns}$ & 0.052 & $\mathrm{~ns}$ & $\mathrm{~ns}$ & - & 72.33 & $(2548)$ & 25.89 & $(2525.9)$ & 0.64 \\
1996 & 0.010 & $\mathrm{~ns}$ & $\mathrm{~ns}$ & 0.026 & $\mathrm{~ns}$ & $\mathrm{~ns}$ & - & 173.59 & $(3800)$ & 67.85 & $(3777.8)$ & 0.61 \\
1997 & $\mathrm{~ns}$ & 0.022 & 0.004 & 0.000 & $\mathrm{~ns}$ & 0.078 & - & 308.47 & $(3018)$ & 150.23 & $(2994.4)$ & 0.51 \\
1998 & 0.006 & 0.008 & 0.044 & 0.000 & $\mathrm{~ns}$ & $\mathrm{~ns}$ & - & 310.04 & $(3728)$ & 171.28 & $(3704.2)$ & 0.45 \\
1999 & 0.002 & 0.050 & 0.000 & 0.000 & 0.006 & $\mathrm{~ns}$ & - & 720.88 & $(3780)$ & 507.61 & $(3756.6)$ & 0.30 \\
All & 0.048 & 0.000 & 0.002 & 0.000 & 0.000 & 0.000 & 0.000 & 5201.80 & $(42760)$ & 3962.32 & $(42732.7)$ & 0.24 \\
\end{tabular}

a biological perspective, we decided not to examine the interaction effects further because of the small improvement in the model fits relative to the increase in the number of covariates and our desire to maintain covariate consistency between annual models. Hence, the final GAMs used in the subsequent analyses only included the effects of the main covariates.

Generally, all the main covariates (depth, temperature, latitude, and longitude) were found to significantly affect the relative abundance of mature cod (Table 1). The effect of each covariate included in the GAMs was conditional on the other covariates in the models, as demonstrated by the fitted contribution of each covariate to the relative abundance of mature cod plotted against the value of the covariate. Results from the individual GAMs demonstrated similar patterns, although in some years significant interannual variability was observed for each covariate (Figs. 4 to 7 ). For each year, the GAMs produced relatively good overall model fits, as demonstrated by the apparent lack of structure in the deviance residuals relative to the predicted values (Fig. 8).

Similar results to the individual-year GAMs were found for the combined data examining the additional temporal effect of year (Table 1 \& Fig. 9). Generally, throughout the survey period, the relative abundance of mature cod was greatest between depths of 100 and $300 \mathrm{~m}$, bottom temperatures of 2 and $6^{\circ} \mathrm{C}$, and locations north of $65^{\circ} \mathrm{N}$ and east of $22^{\circ} \mathrm{W}$ (Fig. 9). These conditions corresponded to the greatest concentrations of mature cod abundance in waters off the southwest, northwest, southeast, and north coasts of Iceland (Fig. 3). However, in some years, mature cod abun- dance was significantly greater in depths $>300 \mathrm{~m}$, temperatures $>6^{\circ} \mathrm{C}$, and locations south of $65^{\circ} \mathrm{N}$ and west of $22^{\circ} \mathrm{W}$ (Figs. 4 to 7 ). Such annual variation may indicate variability in the relative abundance of individual spawning components located within different depth and temperature ranges along the continental edge or in shallower waters closer to shore, particularly on the main spawning grounds off the southwest coast. A significant year effect was also observed on the relative abundance of mature cod throughout the survey period, whereby abundance appeared to decline between 1985 and 1993, before progressively increasing in recent years (between 1994 and 1999: Fig. 9).

\section{Distribution of spawning cod}

The distribution (i.e. presence/absence) of spawning (Stage 3) cod was examined to enable a potentially more accurate evaluation of the covariates affecting regional spawning components compared with the relative abundance patterns of mature cod. Spawning cod were distributed all around Iceland, although generally closer to the shore than mature cod, providing further support for differential regional spawning components (Figs. $3 \& 10$ ).

Overall, the effects of the environmental and locational covariates on the distribution of spawning cod were more significant than the length and age covariates (Table 2). Results similar to those for the individual year GAMs were found for the combined data examining the additional temporal effect of year (Table 2, 

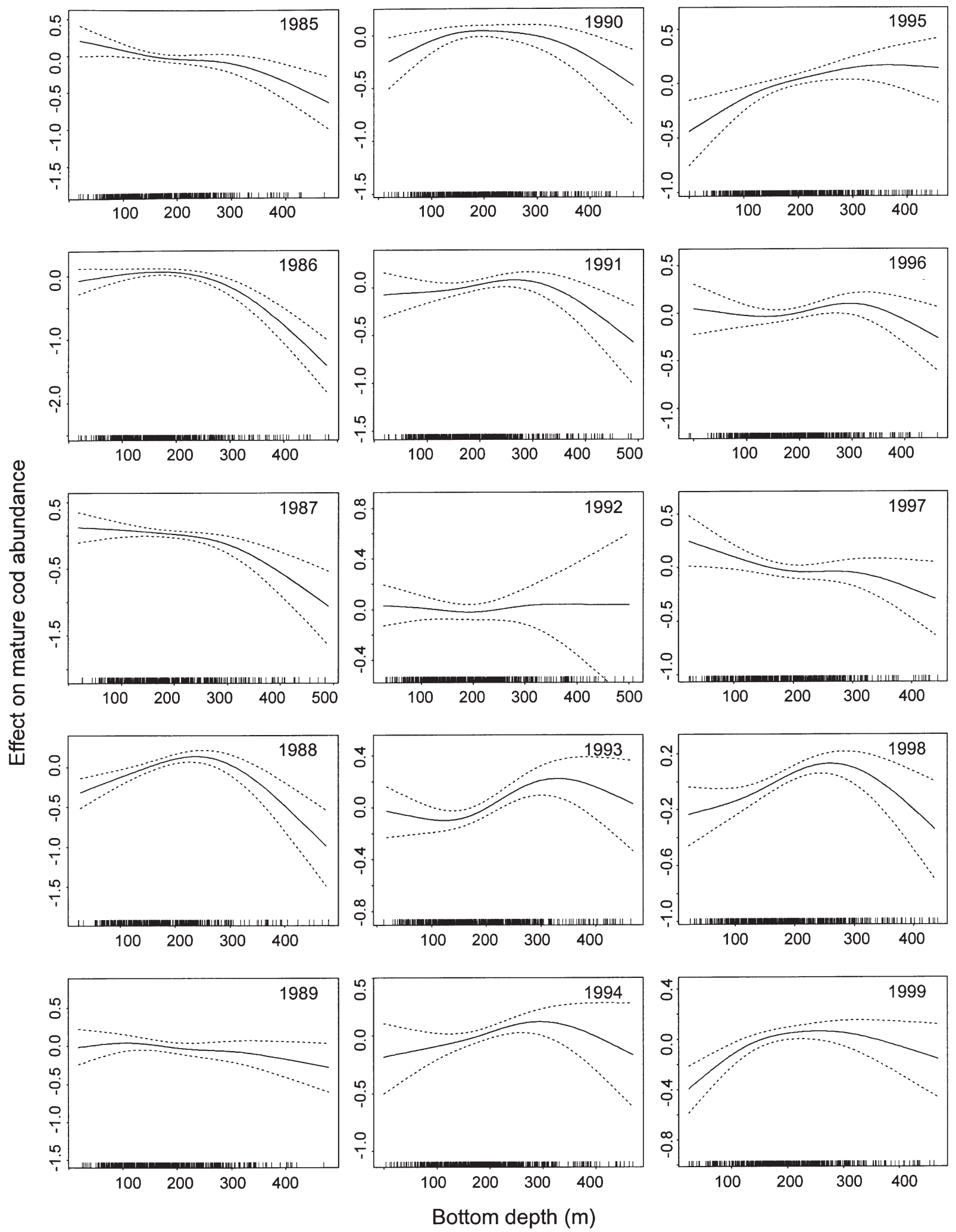

Fig. 4. Gadus morhua. GAM smooths of the conditional effect of bottom depth $(\mathrm{m})$ on the relative abundance of mature cod, 1985 to 1999. The $y$-axis is scaled to zero and reflects the relative importance of the covariate; rugplot on the $x$-axis represents the number of observations; dashed lines are the $95 \%$ confidence intervals on the smooths generated from bootstrap resampling 

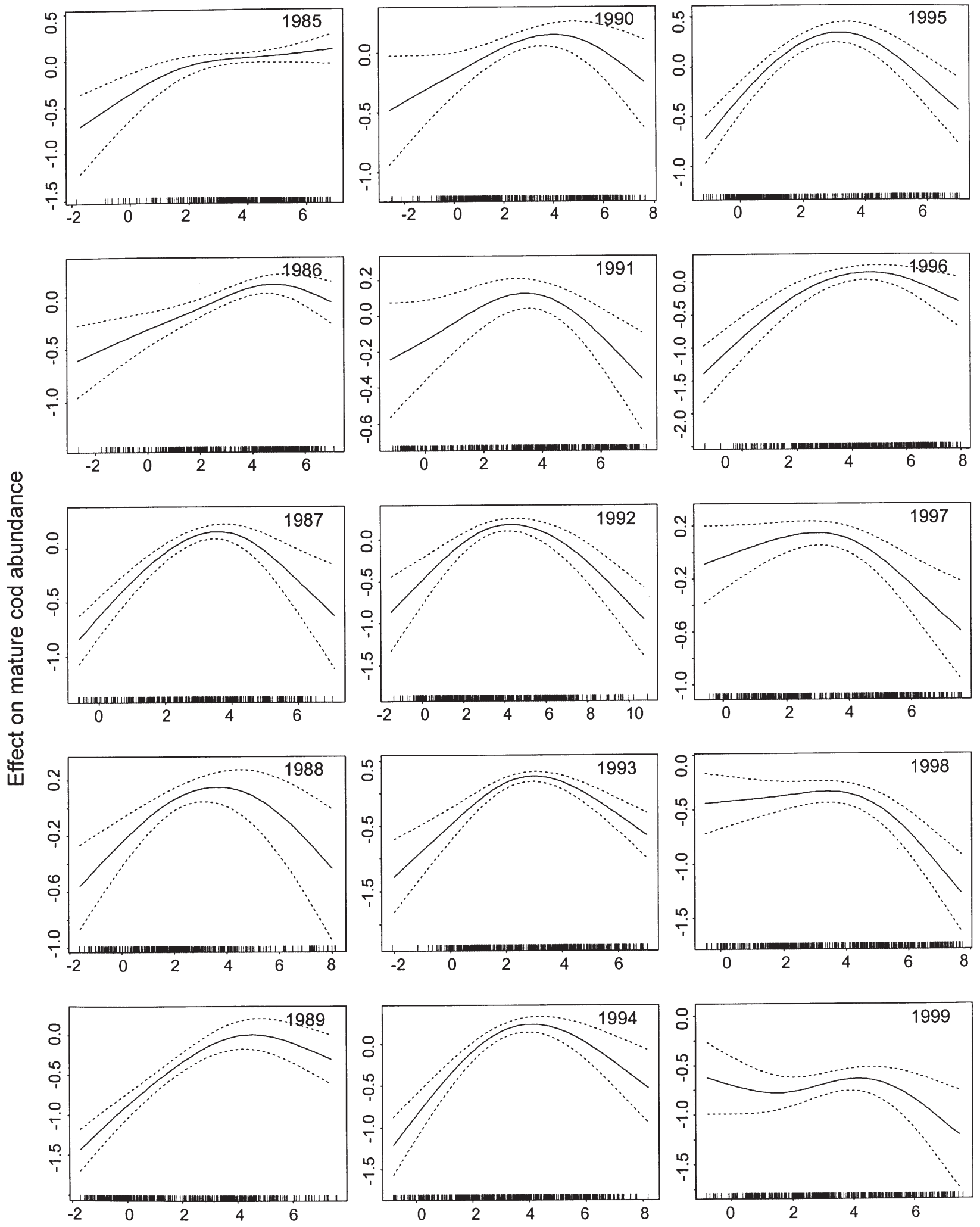

Bottom temperature $\left({ }^{\circ} \mathrm{C}\right)$

Fig. 5. Gadus morhua. GAM smooths of the conditional effect of bottom temperature $\left({ }^{\circ} \mathrm{C}\right)$ on the relative abundance of mature cod, 1985 to 1999. Further details as in Fig. 4 legend 

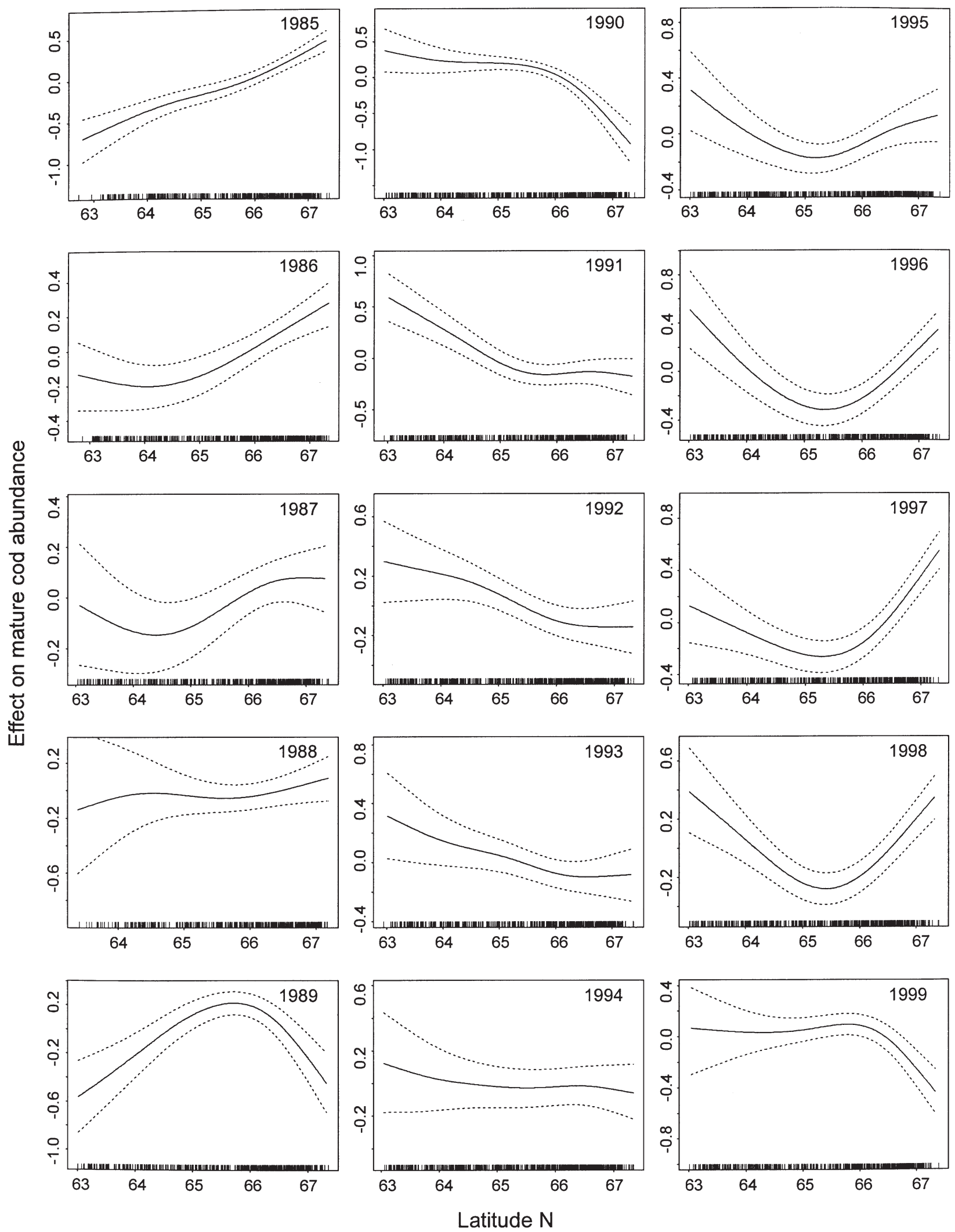

Fig. 6. Gadus morhua. GAM smooths of the conditional effect of latitude $\left({ }^{\circ} \mathrm{N}\right)$ on the relative abundance of mature cod, 1985 to 1999. Further details as in Fig. 4 legend 

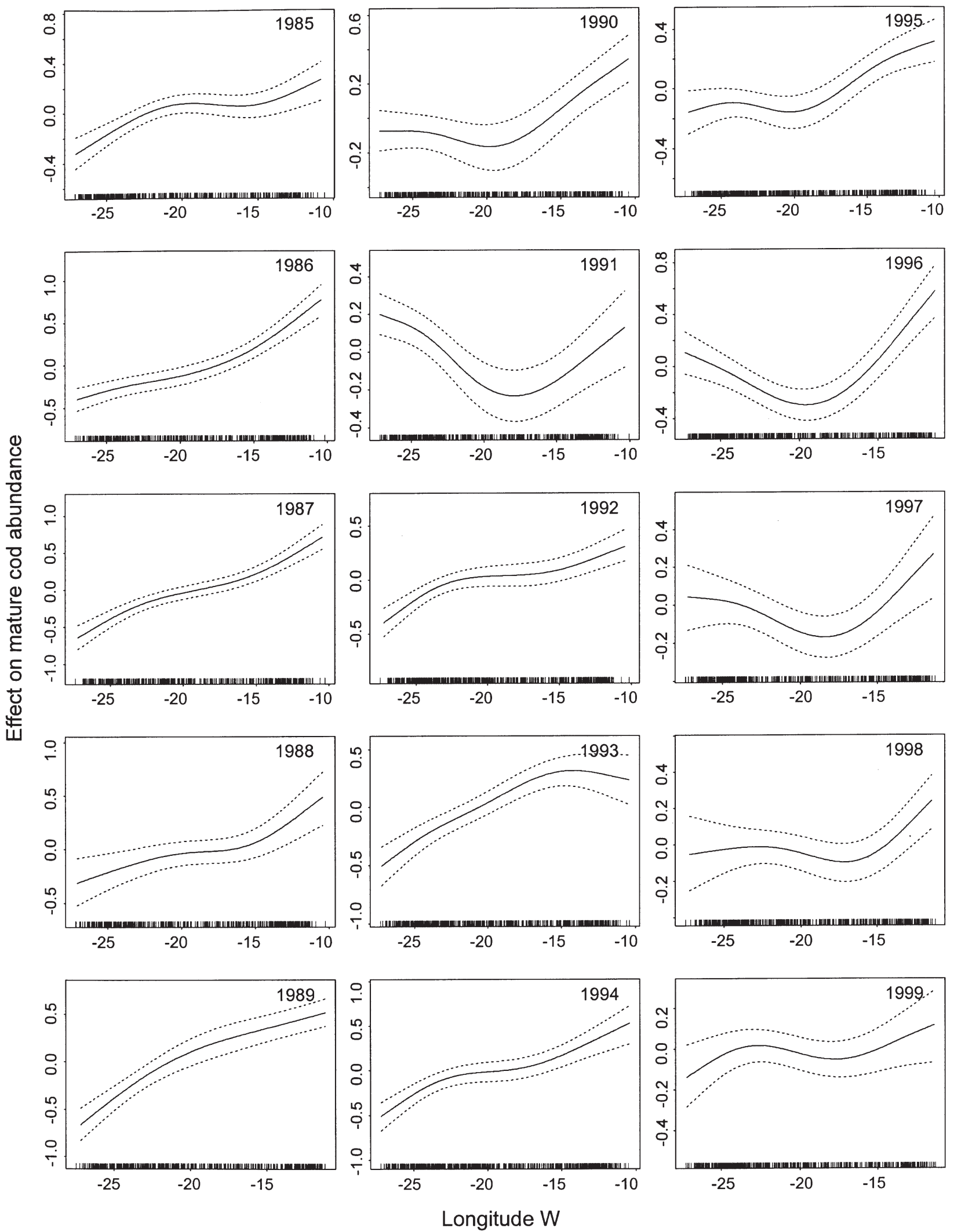

Fig. 7. Gadus morhua. GAM smooths of the conditional effect of longitude $\left({ }^{\circ} \mathrm{W}\right)$ on the relative abundance of mature cod, 1985 to 1999. Further details as in Fig. 4 legend 

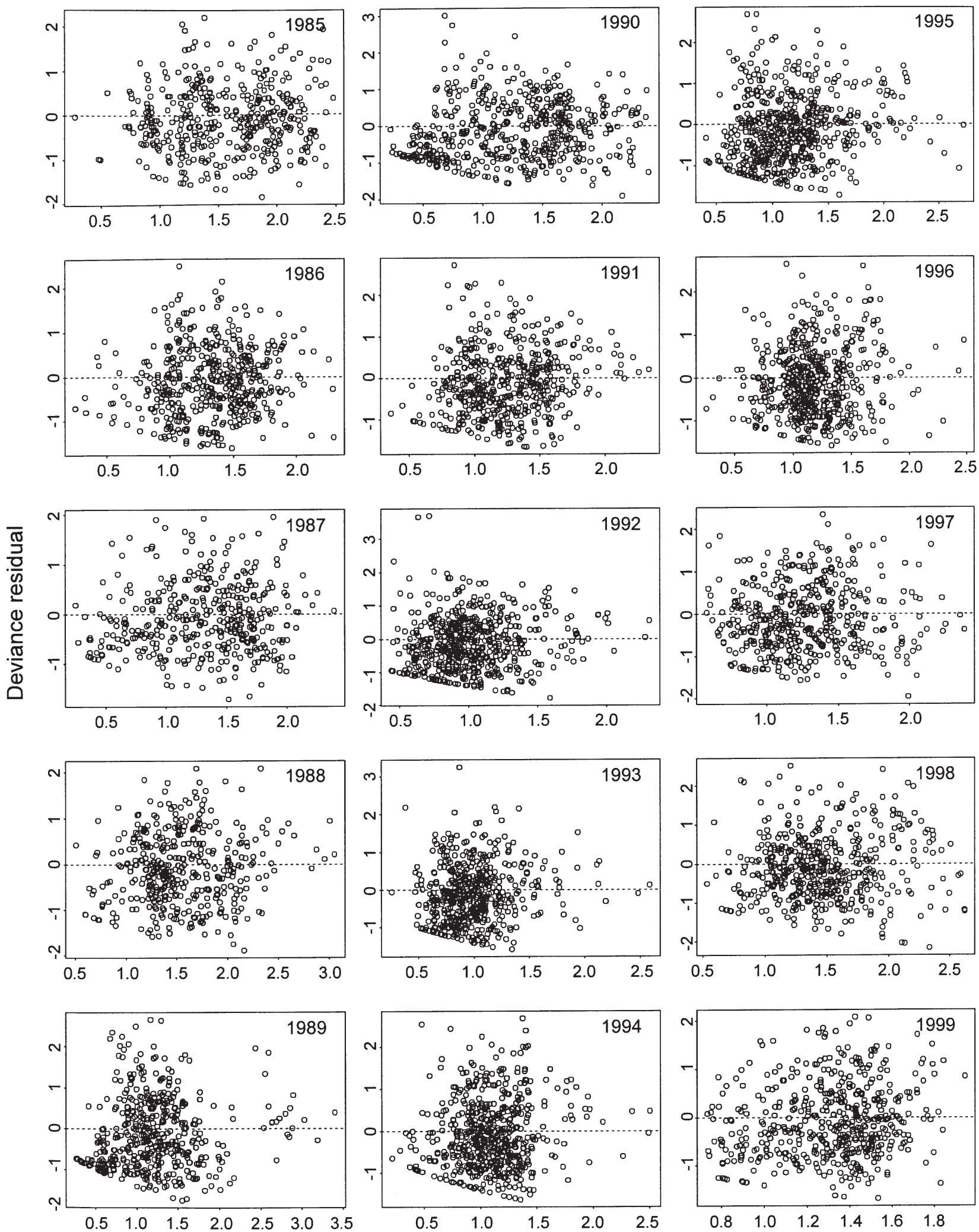

Mature cod abundance predicted value

Fig. 8. Gadus morhua. Plots of the deviance residuals against predicted values from the annual (1985 to 1999) GAMs examining the relative abundance of mature cod 

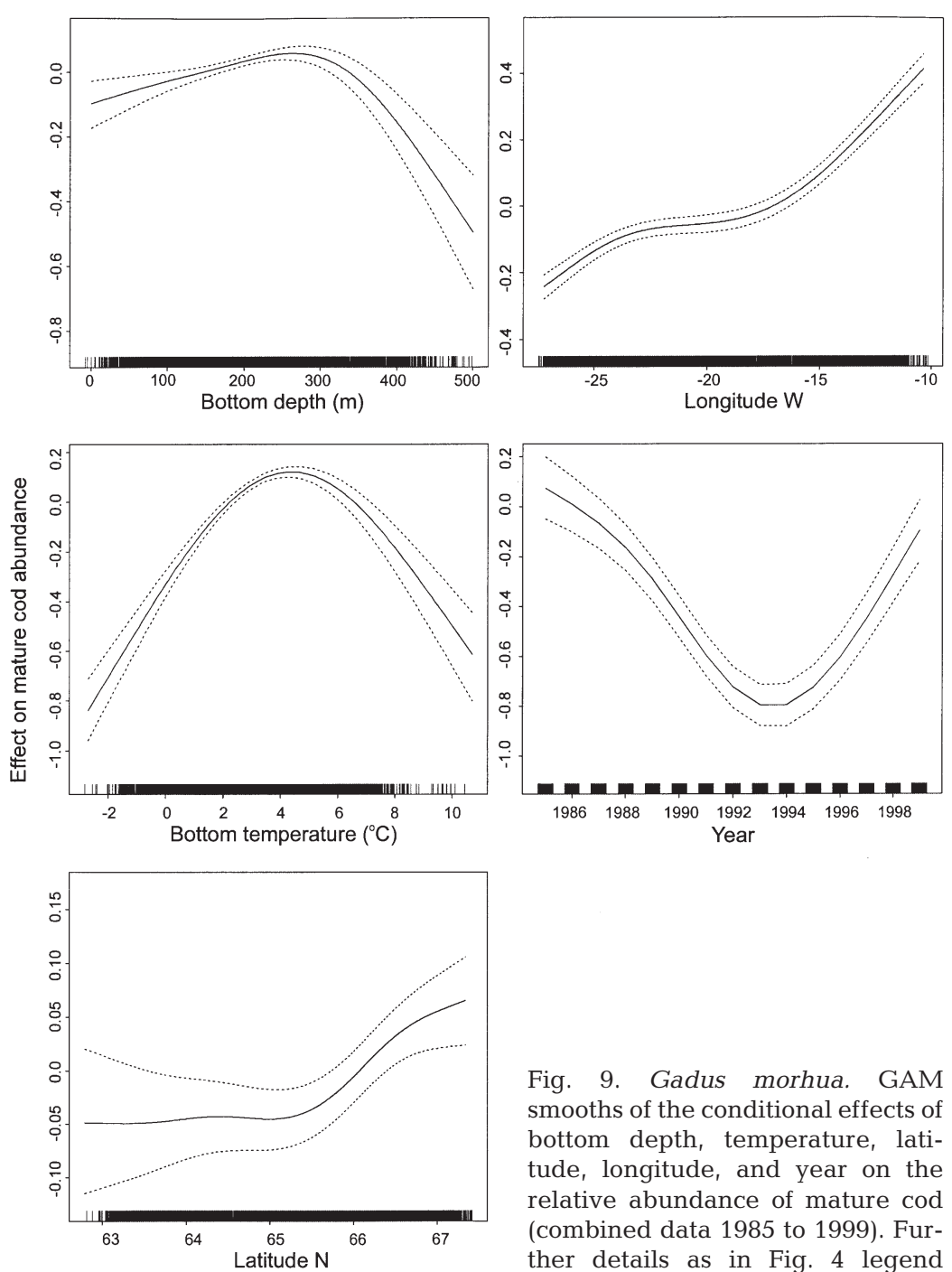

Fig. 9. Gadus morhua. GAM smooths of the conditional effects of bottom depth, temperature, latitude, longitude, and year on the relative abundance of mature cod (combined data 1985 to 1999). Further details as in Fig. 4 legend

the waters around Iceland. Fish stocks comprised of geographically dispersed spawning components, such as the Icelandic cod stock, are more likely to optimize environmental conditions favourable to progeny survival and recruitment success than single isolated spawning stocks, because they have a greater chance of some of their stock encountering favourable conditions in an unpredictable environment (Sinclair 1988, DeYoung \& Rose 1993, Begg \& Marteinsdottir 2000, Marteinsdottir et al. 2000b). Consequently, identifying environmental and biotic effects that influence the distribution and abundance of fish stocks and their composite spawning components will facilitate our understanding of recruitment variability (Hutchings et al. 1993, Daskalov 1999, Marteinsdottir et al. 2000a). In this study, we found depth, temperature, and more importantly location, to be significant covariates affecting the distribution and abundance of mature and spawning cod. Incorporating the effects of these covariates and their underlying relationships into stock and recruitment processes will provide insight into the mechanisms involved in the population structuring of cod in Icelandic waters.

At the onset of peak spawning (March to May), mature cod were located in waters all around Iceland, but with persistent concentrations in any given year (indicative of regional spawning components) off the southwest, south-

Fig. 10). The distribution of spawning cod was greatest in depths down to $300 \mathrm{~m}$, bottom temperatures above $2^{\circ} \mathrm{C}$, and locations around $63.5^{\circ} \mathrm{N}, 66.5^{\circ} \mathrm{N}$, and $21^{\circ} \mathrm{W}$ (Fig. 10). These conditions corresponded to spawning cod in waters off the southwest, northwest, and north coasts of Iceland. In addition, spawning cod 60 to $100 \mathrm{~cm}$ in length and 8 to $10 \mathrm{yr}$ of age were more prevalent with fewer larger and older fish in the stock (Fig. 10). A significant year effect was also observed on the distribution of spawning cod, with an apparent decline between 1988 and 1995, followed by a progressive increase between 1996 and 1999 (Fig. 10).

\section{DISCUSSION}

Large-scale spatial distributions of mature cod indicated differential regional spawning components in east, and north coasts (Fig. 3). Although, the regions where mature cod were sampled may not necessarily be the regions where spawning occurs, other recent studies have indicated regional spawning components in waters around Iceland (Begg \& Marteinsdottir 2000, Marteinsdottir et al. 2000a,b). Persistent commercial catches throughout the spawning season, comprised of spawning cod, have also indicated localized spawning in these regions (Marteinsdottir et al. 2000b, MRI unpubl. data). Moreover, the spawning distributions observed in this study provided direct evidence of regional spawning components (Fig. 10), which may be contributing significantly more to the overall productivity of the stock than has been traditionally accepted (i.e. Sæmundsson 1924, Jónsson 1982). During April and May, pelagic eggs and larvae derived from the main spawning component off the southwest coast drift clockwise around the country, with the 

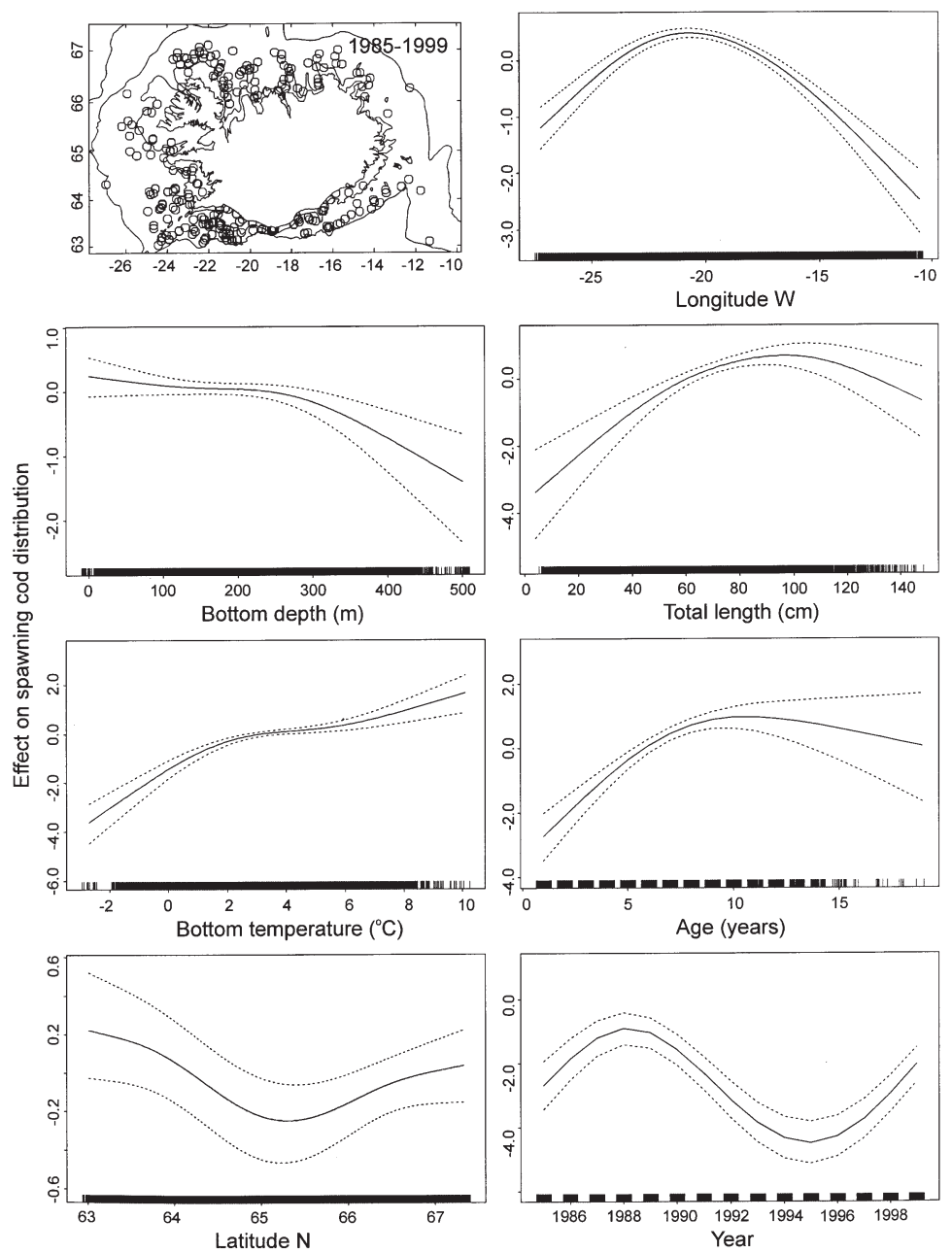

Fig. 10. Gadus morhua. GAM smooths of the conditional effects of bottom depth, temperature, latitude, longitude, length, age, and year on the spatial distribution (i.e. presence/absence) of spawning cod (combined data 1985 to 1999). (O) locations of spawning cod; further details as in Fig. 4 legend

coastal and offshore currents, to the main nursery grounds off the north coast (Astthorsson et al. 1994, Begg \& Marteinsdottir 2000, 2002 this issue). In contrast, back-calculated birth-date distributions of 0-group cod have indicated later spawning, extending into June, for regional spawning components off the north and east coasts, where eggs and larvae are most probably retained within fjords and inshore waters (Begg \& Marteinsdottir 2000, Marteinsdottir et al. 2000b). Likewise, other studies have also demonstrated significant inshore spawning of cod throughout the north Atlantic (Hutchings et al. 1993, Dalley \& Anderson 1997, Marteinsdottir et al. 2000a).

As for many other exploited fish stocks, the Icelandic cod stock has greater spawning diversity than has been traditionally accepted, and could be considered as a metapopulation, with the regional spawning components located around the country being interconnected by dispersal and migration. A metapopulation is a composite of local populations (i.e. spawning components) between which individuals move, and where 'source' populations provide immigrants to less productive or 'sink' populations (Hanski 1991, Tyler \& Rose 1994). Source populations tend to occupy preferred habitats that ensure greatest reproductive success (Pulliam 1988). The main spawning component off the southwest coast may act as the dominant source population for the Icelandic cod stock. The main spawning grounds are characterized by warm Atlantic waters (Valdimarsson \& Malmberg 1999, and present Fig. 3) favourable to fast growth rates and survival of early life history stages while providing the necessary transport mechanism to the main nursery grounds in the north (Begg \& Marteinsdottir 2000, 2002, Marteinsdottir et al. 2000b). The internal dynamics of individual spawning components can significantly affect the dynamics of an entire metapopulation (Tyler \& Rose 1994), stressing the need for studies such as the present one to examine environmental and biotic effects that influence the life history and population dynamics of individual spawning components.

Depth, temperature, and more importantly location, were significant covariates affecting the relative abundance of mature cod and the spatial distribution of spawning cod (Tables 1 \& 2). Recently, GAMs have also been used to identify the effects of these covariates on the adult distribution and abundance of other demersal (Swartzman et al. 1992, O'Brien \& Rago 1996) and pelagic (Swartzman et al. 1994, 1995, Maravelias \& Reid 1997, Maravelias 1999, Maravelias et al. 2000) fish species. Similar environmental and locational effects were found for both mature and spawning cod, albeit with some variation, reflective of differential spawning behaviour of the stock during the spawning season (Figs. $9 \& 10$ ). Generally, spawning cod were distributed within a more defined range of latitude and longitude, and closer to the shore at less depth and warmer temperatures than mature cod. Consequently, this shift in distribution may represent the movement of spawning cod into inshore waters, as well as into the main spawning grounds southwest of the country, at the onset of spawning. In addition, the interannual variation revealed by the GAMs (Figs. 4 to 7 ) indicates that 
this method may be useful for tracking changes in the distribution and abundance of individual spawning components. For example, the reduced effect of longitude between 15 and $20^{\circ} \mathrm{W}$ on the relative abundance of mature cod in 1991, 1997 and 1998, associated with the reduced effect of depth $>300 \mathrm{~m}$, may reflect a decline in the abundance of cod spawning along the edge of the continental shelf off the southeast coast during those years, while the reverse may have occurred in 1993 and 1994.

Generally, mature and spawning cod were prevalent in depths down to $300 \mathrm{~m}$, although inshore waters $(0$ to $100 \mathrm{~m}$ ) were more significant for spawning cod. At the onset of peak spawning, larger and older cod initiate spawning earlier than smaller and younger cod (Jónsson 1982, Marteinsdottir \& Björnsson 1999). Moreover, size- and age-selective spatial segregation occurs on the main spawning grounds, where larger and older cod typically spawn in shallower waters closer to shore, in contrast to smaller and younger cod which spawn in offshore waters on the edge of the continental shelf (Marteinsdottir et al. 2000a). Our results were consistent with these patterns, where greater significance of inshore waters to spawning versus mature cod detected by the GAMs may be reflective of the timing of the surveys at the start of the spawning season. In addition, the significance of inshore waters to spawning cod may be even more pronounced than revealed by our samples, since bottom trawls have been suggested as being inefficient at capturing spawning cod (Hutchings et al. 1993), and inshore waters off the south coast are characterized by untrawlable substratum, resulting in reduced sampling coverage in these waters (Pálsson et al. 1989, Marteinsdottir et al. 2000a).

Mature and spawning cod were also largely distributed within a temperature range of 2 to $8^{\circ} \mathrm{C}$, although lower temperatures were more restrictive to the distribution of spawning cod. Low bottom temperatures have been associated with shifts in distribution (DeYoung \& Rose 1993, Rose et al. 2000) and initiation of spawning (Hutchings \& Myers 1993, Kjesbu 1994), acting as a barrier to migrating cod and a physiological constraint to maturation (Hutchings \& Myers 1994, Brander 1995). Cod are also known to migrate along routes of preferred ambient temperatures (Rose 1993), compensating for fluctuations in temperature by shifting locations to maintain an optimum temperature range (Mountain \& Murawski 1992). Similarly, our results indicate that mature cod maintain an optimum temperature range within Icelandic waters (Fig. 9). Furthermore, spawning cod were more prevalent in warmer waters off the southwest coast at the onset of the spawning season (Fig. 10). Spawning cod were also adversely affected by lower temperatures, but did not appear to be affected in the same fashion by higher temperatures, indicating the greater limitations of colder waters on gonad development and the more conducive affect of warmer waters on spawning and the subsequent growth and survival of early life history stages.

Measures of geographic location (i.e. latitude and longitude) were the most significant covariates affecting the relative abundance of mature cod and the spatial distribution of spawning cod. Results from the GAMs were similar to the observed distributions, indicating persistent spawning components off the southwest, southeast, and north coasts. However, the effect of latitude, and in particular longitude, on the distribution of spawning cod varied from that of mature cod (Figs. $9 \& 10$ ). Spawning cod were more prevalent in warmer waters off the west coast at the onset of peak spawning than mature cod. The reduced distribution of spawning cod in the east and (less so) in the north may partly have been due to bottom temperature: it was possibly too early for spawning in the cooler waters off the east and north coasts when the survey occurred (i.e. Begg \& Marteinsdottir 2000). Alternatively, it may have been due to movement of spawning cod to inshore waters and to the main spawning grounds off the southwest coast at the onset of spawning. Moreover, the effects of length and age on the distribution of spawning cod reflected the greater abundance of larger and older cod at the onset of peak spawning (Jónsson 1982, Marteinsdottir \& Björnsson 1999). In contrast, the reduced effects of length and age on the distribution of spawning cod were related to truncated size distributions due to fishing, which has resulted in a reduction in the numbers of larger and older spawners in the stock (Marteinsdottir \& Thorarinsson 1998).

The differential spawning behaviour of the stock demonstrates the temporal limitations of survey data in this type of study (Swartzman et al. 1992). The survey data we used only provided information on covariates affecting the onset of spawning. Consequently, it would be useful to examine the effects of these covariates over the duration of a spawning season to determine spatially and temporally explicit productivity levels, particularly as spawning patterns change throughout the season, e.g. larger and older cod spawn earlier and over a longer period than smaller and younger cod (Jónsson 1982, Marteinsdottir \& Björnsson 1999). In addition, it would be useful to examine the effects of other potentially important covariates, such as the distribution and abundance of capelin Mallotus villosus, which is the major dietary component of cod and has been postulated to directly influence cod spawning behaviour (Marteinsdottir \& Björnsson 1999).

Potentially, the results of the GAMs can be used to monitor annual changes in the distribution and abundance of the stock, which would be useful for stock 
assessment and management. A simple example of the implications of this type of study is that years of good and bad recruitment can be back-calculated to the appropriate distribution and abundance patterns of mature and spawning fish and the variables that may have influenced these patterns, enabling hypotheses to be formulated and tested. Differentiating the underlying mechanisms that structure and maintain fish populations is essential to understanding stock and recruitment processes, which are often used in formulating biological reference points for management (Cook 1997). Studies such as this are necessary because these mechanisms are not well known, although they most probably depend on environmental and stock conditions (Daskalov 1999). Environmental conditions in concert with population dynamics of a stock, such as length at maturation and density-related affects of stock size, define the biological limits and productivity levels of a spawning stock that need to be considered in fisheries management. Although, the Icelandic cod stock is currently assessed as a single, homogeneous unit, future assessments need to incorporate greater spawning diversity into the modelling process. Regional spawning components could then be used in predictive models to infer starting locations of early life history stages, which are considered to be the principal determinants of year-class strength and recruitment success (Cushing 1990, Mertz \& Myers 1994). If we are to unravel the inherent variability in the ongoing fisheries issue of stock and recruitment, then future studies need to examine individual spawning components more explicitly, as well as the environmental and biotic effects that influence their population dynamics and life history traits.

Acknowledgements. Our thanks to the survey leaders, Olafur K. Palsson, Sigfús A. Schopka, and Sólmundur Einarsson, as well as all the cruise leaders and research scientists for collection of the survey data; Lorna Taylor for invaluable discussions and statistical advice; Gunnar Stefánsson for an initial review of this manuscript; and Brian MacKenzie and 3 anonymous reviewers for their constructive comments. This study was part of the EU funded project, FAIR-PL98-4122, 'An operational model of the effects of stock structure and spatio-temporal factors on recruitment (STEREO)', and was supported by the Icelandic Research Council and the Ministry of Fisheries.

\section{LITERATURE CITED}

Astthorsson OS, Gislason A, Gudmundsdottir A (1994) Distribution, abundance, and length of pelagic juvenile cod in Icelandic waters in relation to environmental conditions. ICES Mar Sci Symp 198:529-541

Begg GA, Marteinsdottir G (2000) Spawning origins of pelagic juvenile cod Gadus morhua inferred from spatially explicit age distributions: potential influences on year-class strength and recruitment. Mar Ecol Prog Ser 202:193-217

Begg GA, Marteinsdottir G (2002) Environmental and stock effects on spawning origins and recruitment of cod Gadus morhua. Mar Ecol Prog Ser 229:263-277

Begg GA, Hare JA, Sheehan DD (1999) The role of life history parameters as indicators of stock structure. Fish Res (Amst) 43:141-163

Brander KM (1995) The effect of temperature on growth of Atlantic cod (Gadus morhua L.). ICES J Mar Sci 52:1-10

Cook RM (1997) The application of a sustainability criterion to demersal stocks in the ICES area. Int Counc Explor Sea Comm Meet 1997/V:7

Cushing DH (1990) Plankton production and year-class strength in fish populations: an update of the match/mismatch hypothesis. Adv Mar Biol 26:249-293

Dalley EL, Anderson JT (1997) Age-dependent distribution of demersal juvenile Atlantic cod (Gadus morhua) in inshore/ offshore northeast Newfoundland. Can J Fish Aquat Sci 54(Suppl 1):168-176

Daskalov G (1999) Relating fish recruitment to stock biomass and physical environment in the Black Sea using generalized additive models. Fish Res (Amst) 41:1-23

DeYoung B, Rose GA (1993) On recruitment and distribution of Atlantic cod (Gadus morhua) off Newfoundland. Can J Fish Aquat Sci 50:2729-2741

Efron B, Tibshirani RJ (1993) An introduction to the bootstrap. Chapman \& Hall, London

Hanski I (1991) Single-species metapopulation dynamics: concepts, models and observations. Biol J Linn Soc 42:17-38

Hastie TJ, Tibshirani RJ (1990) Generalized additive models. Chapman \& Hall, London

Hutchings JA, Myers RA (1993) Effect of age on the seasonality of maturation and spawning of Atlantic cod, Gadus morhua, in the northwest Atlantic. Can J Fish Aquat Sci 50:2468-2474

Hutchings JA, Myers RA (1994) Timing of cod reproduction: interannual variability and the influence of temperature. Mar Ecol Prog Ser 108:21-31

Hutchings JA, Myers RA, Lilly GR (1993) Geographic variation in the spawning of Atlantic cod, Gadus morhua, in the northwest Atlantic. Can J Fish Aquat Sci 50:2457-2467

Jónsson E (1982) A survey of spawning and reproduction of the Icelandic cod. Rit Fiskid 6:1-45

Kjesbu OS (1994) Time of start spawning in Atlantic cod (Gadus morhua) females in relation to vitellogenic oocyte diameter, temperature, fish length and condition. J Fish Biol 45:719-736

Malmberg SA, Kristmannsson SS (1992) Hydrographic conditions in Icelandic waters, 1980-1989. ICES Mar Sci Symp 195:76-92

Maravelias CD (1999) Habitat selection and clustering of a pelagic fish: effects of topography and bathymetry on species dynamics. Can J Fish Aquat Sci 56:437-450

Maravelias CD, Reid DG (1997) Identifying the effects of oceanographic features and zooplankton on prespawning herring abundance using generalized additive models. Mar Ecol Prog Ser 147:1-9

Maravelias CD, Reid DG, Swartzman G (2000) Seabed substrate, water depth and zooplankton as determinants of the prespawning spatial aggregation of North Atlantic herring. Mar Ecol Prog Ser 195:249-259

Marteinsdottir G, Björnsson H (1999) Time and duration of spawning of cod in Icelandic waters. Int Counc Explor Sea Comm Meet 1999/Y:34

Marteinsdottir G, Thorarinsson K (1998) Improving the stockrecruitment relationship in Icelandic cod (Gadus morhua) by including age diversity of spawners. Can J Fish Aquat Sci 55:1372-1377

Marteinsdottir G, Gudmundsdottir A, Porsteinsson V, Stefáns- 
son G (2000a) Spatial variation in abundance, size composition and viable egg production of spawning cod (Gadus morhua L.) in Icelandic waters. ICES J Mar Sci 57:824-830

Marteinsdottir G, Gunnarsson B, Suthers IM (2000b) Spatial variation in hatch date distributions and origin of pelagic juvenile cod in Icelandic waters. ICES J Mar Sci 57: 1184-1197

MathSoft (1998) S-PLUS 5 for unix guide to statistics. Data Analysis Products Division, MathSoft, Seattle, WA

Mertz G, Myers RA (1994) Match/mismatch predictions of spawning duration versus recruitment variability. Fish Oceanogr 3:236-245

Mountain DG, Murawski SA (1992) Variation in the distribution of fish stocks on the northeast continental shelf in relation to their environment, 1980-1989. ICES Mar Sci Symp 195:424-432

O'Brien L, Rago P (1996) An application of the generalized additive model to groundfish data with Atlantic cod off the northeast coast of the United States as an example. Northwest Atl Fish Organ Sci Counc Stud 28:79-95

Pálsson OK, Jonsson E, Schopka SA, Stefánsson G, Steinarsson BÆ (1989) Icelandic groundfish survey data used to improve precision in stock assessments. J Northwest Atl Fish Sci 9:53-72

Parrish RH, Nelson CS, Bakiun A (1981) Transport mechanisms and reproductive success of fishes in the California Current. Biol Oceanogr 1:175-203

Pawson MG, Jennings S (1996) A critique of methods for stock identification in marine capture fisheries. Fish Res (Amst) 25:203-217

Powles PM (1958) Studies of reproduction and feeding of Atlantic cod (Gadus callarias L.) in the southwestern Gulf of St. Lawrence. J Fish Res Board Can 15:1383-1402

Pulliam HR (1988) Sources, sinks and population regulation. Am Nat 132:652-661

Editorial responsibility: Otto Kinne (Editor),

Oldendorf/Luhe, Germany
Rose GA (1993) Cod spawning on a migration highway in the north-west Atlantic. Nature 366:458-461

Rose GA, deYoung B, Kulka DW, Goddard SV, Fletcher GL (2000) Distribution shifts and overfishing the northern cod (Gadus morhua): a view from the ocean. Can J Fish Aquat Sci 57:644-663

Sæmundsson B (1924) Fiskarnir (Pisces Islandiae). Felgasprentsmidjan, Reykjavik

Schopka SA (1994) Fluctuations in the cod stock off Iceland during the twentieth century in relation to changes in the fisheries and environment. ICES Mar Sci Symp 198: 175-193

Sinclair M (1988) Marine populations. An essay on population regulation and speciation. Washington Sea Grant Program University of Washington Press, Seattle, WA

Sokal RR, Rohlf FJ (1995) Biometry. The principles and practice of statistics in biological research, 3rd edn. WH Freeman \& Company, New York

Swartzman G, Huang C, Kaluzny S (1992) Spatial analysis of Bering Sea groundfish survey data using generalized additive models. Can J Fish Aquat Sci 49:943-962

Swartzman G, Stuetzle W, Kulman K, Powojowski M (1994) Relating the distribution of pollock schools in the Bering Sea to environmental factors. ICES J Mar Sci 51:481-492

Swartzman G, Silverman E, Williamson N (1995) Relating trends in walleye pollock (Theragra chalcogramma) abundance in the Bering Sea to environmental factors. Can J Fish Aquat Sci 52:369-380

Tyler JA, Rose KA (1994) Individual variability and spatial heterogeneity in fish population models. Rev Fish Biol Fish 4:91-123

Valdimarsson H, Malmerg SA (1999) Near-surface circulation in Icelandic waters derived from satellite tracked drifters. Rit Fiskid 16:23-39

Submitted: September 1, 2000; Accepted: May 23, 2001

Proofs received from author(s): February 25, 2002 